\title{
Elemental Influence of Eucalyptus Bark Pellet Ash on Corrosion of Tube in Small Boilers
}

\author{
PINIT JIRUKKAKUL ${ }^{1 *}$ and WEERACHAI ARJHARN ${ }^{2}$ \\ ${ }^{1}$ School of Mechanical Engineering, Institute of Engineering, Suranaree University of Technology, \\ Muang, Nakhon Ratchasima 30000, Thailand. \\ ${ }^{2}$ School of Agricultural Engineering, Institute of Engineering,Suranaree University of Technology, \\ Muang, Nakhon Ratchasima 30000, Thailand. \\ *Corresponding author E-mail: j_pinit12@yahoo.com \\ http://dx.doi.org/10.13005/ojc/330630
}

(Received: May 27, 2017; Accepted: July 01, 2017)

\begin{abstract}
The elementary ash in eucalyptus bark affects the corrosion and efficiency of pipes in the boiler tube applying in food industries. The eucalyptus bark had high chloride content at 0.660 $1.975 \%$, which reacted with compound gaseous to form potassium chloride. The most oxide value $(62.66 \%)$ of fresh eucalyptus bark was from calcium oxide, which promoted agglomeration. Reduction of agglomeration may be done by addition of kaolin. Therefore, kaolin was added into eucalyptus bark pellet for 5,10 , and $12 \%$ before using as fuel to produce steam compared with control (pellet without kaolin). The results showed that the tendency for fouling and agglomeration was decreased when 10 and $12 \%$ kaolin was added. At 10\% kaolin addition, the slagging ash was lowest and the agglomeration was reduced for $77.4 \%$. The eucalyptus bark pellet with $10 \%$ kaolin was the most effective fuel for water tube boilers.
\end{abstract}

Keywords: Eucalyptus bark pellet, Boiler, Fouling, Slagging, Agglomeration.

\section{INTRODUCTION}

Eucalyptus wood is considered a major economic wood in Thailand, and it is an important raw material in pulp production'. In 2002, Thai industries' utilization of eucalyptus wood amounted to 11 Mton. This included 6.5 Mton or $60 \%$ of utilization for pulp production and export wood chip, and 3.5 Mton or $30 \%$ of utilization for wood chip fuel. The processing of eucalyptus for the paper industry creates a by-product, which is bark. In Thailand, the by-product of bark created by the paper industry amounts to $20 \%$ of the fresh wood or 1.3 Mton per year, and 281.90 ktoe (crude oil equivalent) ${ }^{2}$. In 2004, Thai pulp industries' demand was increasing of eucalyptus wood logs amounted to $7 \mathrm{Mton}$. This included 4.71 Mton for short fiber pulp production and 2.29 Mton for wood chip fuel and construction. Thus, a growth campaign led by private companies that use eucalyptus wood for 
pulp production has resulted in the continuous development of species, the area cultivated with eucalyptus expanded of eucalyptus wood was produced for industrial extension.

Most eucalyptus bark has been used as fuel for biomass power plants ${ }^{3}$. These plants mix the bark with other types of biomass such as wood chips, husks, or coal to overcome the bark's unsuitable properties. The Japan Institute of energy ${ }^{4}$ reported coal with $20 \%$ biomass affected the higher heating efficiency than coal with $25 \%$ biomass. There are many technologies to increase the efficiency by change the physical and chemical properties of biomass for the suitable utilization ${ }^{5}$. Theis, Skrifvars, Hupa and $\operatorname{Tran}^{6}$ reported the $30 \%$ eucalyptus could be added to coal fuel. The physical properties of eucalyptus bark include a low density and high moisture content (about 30-60\%). The chemical properties include alkalinity with high sodium, potassium, calcium, and magnesium, which change to vapor and distill on tubing when heated. The sulfur dioxide is sulphate compound which has a low melting point and becomes a sticky stain on the tube surface and clings to ash, causing corrosion and fouling of the tube system, as well as slagging. Finally, it affects the efficiency of the heating production system and contributes to the deterioration of the boiler's useful life.

The boiler was important machine for food production because steam widely employed in thermal food industry processes for reducing microbial charge and enzymatic activity to maintain quality of food product and reducing deterioration. Generally, Food industry processes require the supplying of large quantities of saturated or superheated steam during short periods of time ${ }^{7}$. Thus, the water tube boiler is selected in food industry because it generates large amount of steam in the short time with its small size.

Investigations into eucalyptus bark processing have resulted in studies on pellets, shreds, and biomass moisture reduction. Eucalyptus bark testing for combustion technology has studies for direct combustion in water tube boiler. The objectives for this current experiment were to study and develop eucalyptus bark processing and its using water tube boiler in the small industrial factory. The study observed thermochemical behavior and the effects of using an additive on efficiency and the useful life of the boiler by conducting an analysis of the oxide components in the combustion system. Corrosion in the tube, fouling, and slagging in the combustion chamber were all investigated. The study aimed to find a strategy for utilizing eucalyptus bark that would not affect efficiency or the boiler's useful life.

\section{MATERIALS AND METHODS}

\section{The properties of eucalyptus bark}

Eucalyptus bark was surveyed and samples were taken from factories in Northeast of Thailand. The moisture content of the eucalyptus bark was determined using the ASTM D $3173^{\circ}$ standard test method. The appearance and density of pieces and shreds of eucalyptus were determined according to eucalyptus bark in cubic dimensions of $30 \times 30 \times 30 \mathrm{~cm}^{3}$, which were weighed on site. The proximate analysis of eucalyptus bark was determined following ASTM D1762-84 ${ }^{9}$ and ASTM D2015- $77^{10}$ standard test methods. The ultimate analysis of $\mathrm{C}, \mathrm{H}, \mathrm{N}, \mathrm{S}$, and $\mathrm{O}$ was determined using a CHNS elemental analyzer (LECO model CHNS-932 California, USA). The oxide analysis of eucalyptus bark, including analyses of $\mathrm{Na}_{2} \mathrm{O}, \mathrm{MgO}, \mathrm{Al}_{2} \mathrm{O}_{3}, \mathrm{SiO}_{2}$, $\mathrm{P}_{2} \mathrm{O}_{5}, \mathrm{~K}_{2} \mathrm{O}, \mathrm{CaO}, \mathrm{SO}_{3}, \mathrm{MnO}$, and $\mathrm{Fe}_{2} \mathrm{O}_{3}$, was determined using an Energy Dispersive X-Ray Fluorescence Spectrometer (EDXRF) (Oxford model ED 2000, United Kingdom).

\section{Fuel preparation}

The moisture content of eucalyptus bark collected from factories was reduced using a sun dryer, and then the bark was chopped to a bulk density of $110 \mathrm{~kg} / \mathrm{m}^{3}$ using a hammer mill. The shreds of eucalyptus bark were compressed with a pelletizing machine (TPM 520-138 model, Thailand). By testing, eucalyptus bark pellet was mixed with kaolin which was purchased from Siam Soil Co. Ltd., Thailand. The kaolin was added to the pellet ingredients in 5,10 , and $12 \% \mathrm{w} / \mathrm{w}$ for boiler testing. The pellets were prepared with $8 \mathrm{~mm}$ diameters, $11-13 \%$ w.b. moisture content, and $715 \mathrm{~kg} / \mathrm{m}^{3}$ bulk density. The power utilization of eucalyptus bark pellet production was $100.5 \mathrm{~kW}$.h/ton. Steam boiler for the test could the maximum vapor production rate was $500 \mathrm{~kg} / \mathrm{h}$, and pressure was 22 bar with stoker feeding of biomass. Eucalyptus bark pellets were compared with and without kaolin added in 
terms of fouling, corrosion, and agglomeration of tubing in the boiler.

\section{Oxide analyses of eucalyptus bark ash}

An oxide analyses of the ashes, including analyses of $\mathrm{Na}_{2} \mathrm{O}, \mathrm{MgO}, \mathrm{Al}_{2} \mathrm{O}_{3}, \mathrm{SiO}_{2}, \mathrm{P}_{2} \mathrm{O}_{5}, \mathrm{~K}_{2} \mathrm{O}, \mathrm{CaO}$, $\mathrm{SO}_{3}, \mathrm{MnO}$, and $\mathrm{Fe}_{2} \mathrm{O}_{3}$, was determined using the Energy Dispersive X-Ray Fluorescence Spectrometer (EDXRF) (Oxford model ED 2000, United Kingdom). The analysis of the influence on the boiler and tubing, the ash content, and ash agglomeration of the biomass were determined and weights were taken on site.
Risk assessment of fouling and slagging indices based on ash composition

Given the analysis of oxide components in the eucalyptus bark ash, the components' effects on boiler tube potential were assessed using three separate indices, the Al (Alkali Index), the $R_{b / a}$ (Base to Acid Ratio), and the BAI (Bed Agglomeration Index), as follows:

$$
\begin{aligned}
& \mathrm{Al}=\mathrm{kg}\left(\mathrm{K}_{2} \mathrm{O}+\mathrm{Na}_{2} \mathrm{O}\right) / \mathrm{GJ} \\
& \mathrm{R}_{\mathrm{b} / \mathrm{a}}=\%\left(\mathrm{Fe}_{2} \mathrm{O}_{3}+\mathrm{CaO}+\mathrm{MgO}+\mathrm{K}_{2} \mathrm{O}+\mathrm{Na}_{2} \mathrm{O}\right) / \\
& \%\left(\mathrm{SiO}_{2}+\mathrm{TiO}_{2}+\mathrm{Al}_{2} \mathrm{O}_{3}\right) \\
& \mathrm{BAI}=\%\left(\mathrm{Fe}_{2} \mathrm{O}_{3}\right) / \%\left(\mathrm{~K}_{2} \mathrm{O}+\mathrm{Na}_{2} \mathrm{O}\right)
\end{aligned}
$$

\begin{tabular}{|c|c|c|c|c|c|c|c|c|c|c|}
\hline \multirow[t]{2}{*}{ Fuel } & \multicolumn{9}{|c|}{ Composition (\% Oxides in fuel) } & \multirow[b]{2}{*}{$\mathrm{SO}_{3}$} \\
\hline & $\mathrm{SiO}_{2}$ & $\mathrm{Al}_{2} \mathrm{O}_{3}$ & $\mathrm{Fe}_{2} \mathrm{O}_{3}$ & $\mathrm{~K}_{2} \mathrm{O}$ & $\mathrm{TiO}_{2}$ & $\mathrm{MgO}$ & $\mathrm{CaO}$ & $\mathrm{Na}_{2} \mathrm{O}$ & $\mathrm{P}_{2} \mathrm{O}_{5}$ & \\
\hline Fresh eucalyptus bark & 4.62 & 0.93 & 2.05 & 17.09 & 0.53 & 0.86 & 62.66 & 3.28 & 0.73 & 1.85 \\
\hline Bottom ash of pellet & 56.53 & 9.64 & 4.58 & 2.62 & 1.35 & 3.48 & 15.64 & N.D. & 3.28 & N.D. \\
\hline $\begin{array}{l}\text { Bottom ash of pellet with } \\
5 \% \text { kaolin }\end{array}$ & 63.26 & 10.46 & 4.61 & 2.81 & 1.04 & 2.70 & 12.33 & N.D. & 1.79 & N.D. \\
\hline $\begin{array}{l}\text { Bottom ash of pellet with } \\
10 \% \text { kaolin }\end{array}$ & 68.74 & 10.27 & 3.20 & 2.60 & 1.03 & 1.85 & 10.04 & N.D. & 1.46 & N.D. \\
\hline $\begin{array}{l}\text { Bottom ash of pellet with } \\
12 \% \text { kaolin }\end{array}$ & 66.04 & 11.82 & 3.72 & 2.84 & 0.89 & 1.99 & 9.74 & N.D. & 1.48 & N.D. \\
\hline Fly ash of pellet & 43.65 & 6.96 & 5.13 & 3.18 & 1.53 & 4.74 & 18.27 & N.D. & N.D. & 9.79 \\
\hline $\begin{array}{l}\text { Fly ash of pellet with } \\
5 \% \text { kaolin }\end{array}$ & 59.38 & 10.54 & 3.88 & 3.31 & 0.99 & 3.76 & 10.32 & N.D. & N.D. & 4.81 \\
\hline $\begin{array}{l}\text { Fly ash of pellet with } \\
10 \% \text { kaolin }\end{array}$ & 58.08 & 11.27 & 3.55 & 3.67 & 0.97 & 3.60 & 10.45 & N.D. & N.D. & 5.18 \\
\hline $\begin{array}{l}\text { Fly ash of pellet with } \\
12 \% \text { kaolin }\end{array}$ & 67.33 & 12.11 & 3.06 & 3.64 & 0.73 & 2.24 & 6.26 & N.D. & 1.34 & 2.77 \\
\hline
\end{tabular}

Table. 1: Oxides of fresh eucalyptus bark and pellets

\begin{tabular}{|c|c|c|c|c|c|c|}
\hline \multirow[t]{2}{*}{ Fuel } & \multicolumn{3}{|c|}{ Bottom ash } & \multicolumn{3}{|c|}{ Fly ash } \\
\hline & $\mathrm{Al}$ & $\mathrm{R}_{\mathrm{b} / \mathrm{a}}$ & BAI & $\mathrm{Al}$ & $\mathrm{R}_{\mathrm{b} / \mathrm{a}}$ & BAI \\
\hline Fresh eucalyptus bark & 0.94 & 0.12 & 13.45 & - & - & - \\
\hline Eucalyptus bark pellets & 0.14 & 1.75 & 0.34 & 0.18 & 1.61 & 0.60 \\
\hline Pellet with $5 \%$ Kaolin & 0.16 & 1.64 & 0.26 & 0.18 & 1.17 & 0.30 \\
\hline Pellet with $10 \%$ Kaolin & 0.14 & 1.23 & 0.20 & 0.20 & 0.97 & 0.30 \\
\hline Pellet with $12 \%$ Kaolin & 0.16 & 1.31 & 0.21 & 0.20 & 0.84 & 0.19 \\
\hline Tendency of slagging and fouling & $0.17>0.34$ & $>2.6$ & $<0.15$ & $0.17>0.34$ & $>2.6$ & $<0.15$ \\
\hline Slagging and fouling begins to occur & $>0.34$ & & & $>0.34$ & & \\
\hline
\end{tabular}

*N.D.: not determine; All values are mean of three replicate experiments

Table. 2: Risk assessments to fouling and slagging

All values are mean of three replicate experiments 
An $\mathrm{Al}$ value higher than $0.17 \mathrm{~kg} / \mathrm{GJ}$ signifies a risk of fouling and slagging, while a value higher than $0.34 \mathrm{~kg} / \mathrm{GJ}$ signifies a tendency for fouling and slagging.

The BAI value was lower than 0.15, signifying an effect on bed agglomeration.

The $R_{b / a}$ value showed trends of metal components in ash, including melting and slagging

\section{Thermal efficiency of fuel}

Thermal efficiency was evaluated using the DIN EN 2032 standard test method ${ }^{11}$. It was calculated by comparing the sensible heat of water with the sensible heat of combustion, which was expressed with the boiling water time, as shown in equation (4). The pressure of the boiler was set at 10-12 bar and the air feed supplied $10-15 \%$ excess air. The exposed air was analyzed using a flue gas analyzer (Model Testo-350XL).

$\eta_{\text {Boiler }}=m_{\text {water }}^{\circ}\left(h_{\text {steam }}-h_{\text {water }}\right) / m_{\text {fuel }}^{\circ}(L H V)$

$\mathrm{m}^{\circ}{ }_{\text {water }}=$ mass flow rate of steam production $(\mathrm{kg}$ steam $/ \mathrm{h}$ )

$\mathrm{m}_{\text {fuel }}^{\circ}=$ fuel feed rate $(\mathrm{kg} / \mathrm{h})$

$\mathrm{h}_{\text {water }}=$ enthalpy of feed water $(\mathrm{kJ} / \mathrm{kg})$

$\mathrm{h}_{\text {steam }}=$ enthalpy of steam $(\mathrm{kJ} / \mathrm{kg})$

$\mathrm{LHV}=$ lower heating value of eucalyptus fuel $(\mathrm{kJ} / \mathrm{kg})$

Table. 3: Oxides of agglomeration of pellet

\begin{tabular}{|c|c|c|c|c|c|c|c|c|c|c|}
\hline \multirow[t]{2}{*}{ Agglomeration } & \multicolumn{9}{|c|}{ Composition (\% Oxide in fuel) } & \multirow[b]{2}{*}{$\mathrm{SO}_{3}$} \\
\hline & $\mathrm{SiO}_{2}$ & $\mathrm{Al}_{2} \mathrm{O}_{3}$ & $\mathrm{Fe}_{2} \mathrm{O}_{3}$ & $\mathrm{~K}_{2} \mathrm{O}$ & $\mathrm{TiO}_{2}$ & $\mathrm{MgO}$ & $\mathrm{CaO}$ & $\mathrm{Na}_{2} \mathrm{O}$ & $\mathrm{P}_{2} \mathrm{O}_{5}$ & \\
\hline Pellet (on tube surface) & 10.99 & 1.69 & 82.93 & 1.34 & N.D. & N.D. & 0.80 & N.D. & N.D. & 1.18 \\
\hline $\begin{array}{l}\text { Pellet with } 5 \% \text { kaolin } \\
\text { (on tube surface) }\end{array}$ & 55.62 & 11.03 & 22.99 & 2.84 & 0.40 & 1.30 & 2.74 & N.D. & N.D. & 2.51 \\
\hline $\begin{array}{l}\text { Pellet with } 10 \% \text { kaolin } \\
\text { (on tube surface) }\end{array}$ & 65.84 & 12.37 & 9.44 & 3.77 & 0.59 & 1.14 & 3.14 & N.D. & N.D. & 3.26 \\
\hline $\begin{array}{l}\text { Pellet with } 12 \% \text { kaolin } \\
\text { (on tube surface) }\end{array}$ & 51.88 & 10.56 & 28.48 & 2.99 & 0.34 & N.D. & 2.04 & N.D. & N.D. & 3.24 \\
\hline Pellet (in bottom ash) & 80.22 & 5.17 & 3.37 & 1.49 & 0.78 & 1.38 & 6.47 & N.D. & 0.50 & N.D. \\
\hline $\begin{array}{l}\text { Pellet with } 5 \% \text { kaolin } \\
\text { (in bottom ash) }\end{array}$ & 78.65 & 6.45 & 3.32 & 1.54 & 0.75 & 1.70 & 6.25 & N.D. & 0.74 & 0.08 \\
\hline $\begin{array}{l}\text { Pellet with 10\% kaolin } \\
\text { (in bottom ash) }\end{array}$ & 77.44 & 6.24 & 3.70 & 1.71 & 0.83 & 1.71 & 6.79 & N.D. & 0.89 & 0.08 \\
\hline $\begin{array}{l}\text { Pellet with } 12 \% \text { kaolin } \\
\text { (in bottom ash) }\end{array}$ & 77.70 & 6.52 & 3.62 & 1.61 & 0.83 & 1.41 & 6.90 & N.D. & 0.79 & N.D. \\
\hline
\end{tabular}

*: N.D. means not determine; All values are mean of three replicate experiments

Table. 4: Steam production and performance of boiler

\begin{tabular}{lccccccc}
\hline Fuel & $\begin{array}{c}\text { Enthalpy } \\
\text { of water } \\
(\mathrm{KJ} / \mathrm{kg})\end{array}$ & $\begin{array}{c}\text { Steam } \\
\text { temp. } \\
\left({ }^{\circ} \mathrm{C}\right)\end{array}$ & $\begin{array}{c}\text { Enthalpy } \\
\text { of steam } \\
(\mathrm{KJ} / \mathrm{kg})\end{array}$ & $\begin{array}{c}\text { Stream } \\
\text { pressure } \\
(\text { bar })\end{array}$ & $\begin{array}{c}\text { Rate of } \\
\text { steam } \\
\text { Production } \\
(\mathrm{kg} / \mathrm{h})\end{array}$ & $\begin{array}{c}\text { Fuel } \\
\text { Consu- } \\
\mathrm{mption} \\
(\mathrm{kg} / \mathrm{h})\end{array}$ & $\begin{array}{c}\text { Efficiency } \\
(\%)\end{array}$ \\
\hline Eucalyptus bark pellets & 410.61 & 186.7 & 2783.5 & 11.7 & 409.2 & 128 & 53.6 \\
Pellet with 5\% Kaolin & 402.18 & 185.5 & 2782.7 & 11.4 & 377.4 & 131 & 48.5 \\
Pellet with 10\% Kaolin & 402.18 & 181.9 & 2779.8 & 10.5 & 366.3 & 157 & 39.2 \\
Pellet with 12\% Kaolin & 389.34 & 167 & 2765.5 & 7.4 & 447.4 & 155 & 48.5 \\
\hline
\end{tabular}


Table. 5: The rate of fouling, flue consumption, and bottom ash of the boiler

\begin{tabular}{lccccc}
\hline Fuel & $\begin{array}{c}\text { Rate of } \\
\text { fouling } \\
\left(\mathrm{g} / \mathrm{m}^{2} . \mathrm{h}\right)\end{array}$ & $\begin{array}{c}\text { Fuel } \\
\text { Consumption } \\
(\mathrm{kg} / \mathrm{h})\end{array}$ & $\begin{array}{c}\text { Powder } \\
\text { ash }\end{array}$ & $\begin{array}{c}\text { Bottom ash(\%) } \\
\text { Slagging } \\
\text { ash }\end{array}$ & $\begin{array}{c}\text { All } \\
\text { ash }\end{array}$ \\
\hline Eucalyptus bark pellets & 283.3 & 128 & 20.0 & 24.4 & 44.4 \\
Pellet with 5\% Kaolin & 115.7 & 131 & 26.0 & 15.0 & 41.0 \\
Pellet with 10\% Kaolin & 64.0 & 157 & 22.4 & 13.6 & 36.0 \\
Pellet with 12\% Kaolin & 53.3 & 155 & 18.0 & 17.3 & 35.3 \\
\hline
\end{tabular}

All values are mean of three replicate experiments

\section{RESULTS AND DISCUSSION}

\section{Properties of eucalyptus bark from Northeast of Thailand}

The 20 provinces in Northeast of Thailand had 64 eucalyptus wood chip factories which were classified as 44 eucalyptus wood chip factories and 20 specific wood chip factories. Nakhon Ratchasima, Surin, and Buriram Provinces had the most eucalyptus wood chip factories in descending order. Eucalyptus wood was brought to the factories in amounts of approximately 5.09 Mton/year, including approximately $1.04 \mathrm{Mton} /$ year of eucalyptus bark. The eucalyptus bark was $20.5 \%$ of the fresh wood, with bark 4-6 cm thick and having a 59-63\% initial moisture content, as measured on site. The density of the eucalyptus bark pieces and shreds was 127.5 and $215.4 \mathrm{~kg} / \mathrm{m}^{3}$, respectively. The pellets had an average density and moisture content of $715.0 \mathrm{~kg} / \mathrm{m}^{3}$ and $11-13 \%$ w.b., respectively, and a diameter of $8 \mathrm{~mm}$. The physical and chemical properties of the rice husk and sub-bituminous were similar to eucalyptus bark, but eucalyptus bark was high chlorine $(0.660-1.975 \%)$ which causes corrosion of the tubes in the boiler.

\section{The oxide analyses of eucalyptus bark and bottom ash of pellets}

The elemental oxide analyses of the fresh eucalyptus bark and bottom ash of pellets were expressed as the weight percentages of oxides in the ash (Table. 1). The findings showed oxides in the fresh eucalyptus bark to be $\mathrm{CaO}, \mathrm{K}_{2} \mathrm{O}, \mathrm{SiO}_{2}$, $\mathrm{Na}_{2} \mathrm{O}, \mathrm{Fe}_{2} \mathrm{O}_{3}$, and $\mathrm{SO}_{3}$ at 62.66, 17.09, 4.62, 3.28, 2.05 , and 1.85 , respectively. The highest oxide concentration in the fresh eucalyptus bark was calcium oxide, which affected particle or aerosol distribution and adhesion to the surface of the tube.
Condensation on the tube's surface from the gas phase to the cooling phase caused agglomeration. Corrosion was caused by the gas phase of $\mathrm{Cl}, \mathrm{K}$, $\mathrm{Na}, \mathrm{S}$, and other heavy metals to compound gases, such as $\mathrm{KCl}, \mathrm{K}_{2} \mathrm{SO}_{4}$, and other heavy metal compounds before condensation on the tube's surface.

The oxide analyses of the bottom ash of the pellets showed eucalyptus bark pellet ash mainly retained $\mathrm{SiO}_{2}, \mathrm{CaO}$, and $\mathrm{Al}_{2} \mathrm{O}_{3}$ (Table 1). The ash produced through burning of the eucalyptus bark pellets expressed a decrease in calcium oxide from 62.66 to $15.64-9.74 \%$ depending on the amount of kaolin added. The $\mathrm{CaO}$ particles were released and the fuel and aerosol were converted to fine ash or exhaust gas. The kaolin content caused an increase in aluminum oxide and silicone oxide, which influenced temperature in the combustion chamber. Characterizations of fouling and slagging tendencies were expressed in terms of the $\mathrm{Al}, \mathrm{R}_{\mathrm{b} / \mathrm{a}}$ and $\mathrm{BAl}$ represented above in equations (1)-(3). Findings showed the probability of slagging, fouling, and agglomeration. The Al was 0.14-0.16 (less than 0.17), signifying a lower tendency for slagging and fouling; the BAI was 0.20 0.34 (more than 0.15 ), signifying no agglomeration occurrence; and the $\mathrm{R}_{\mathrm{b} / \mathrm{a}}$ was 1.23-1.75 (less than 2.6), signifying no tendency for slagging and fouling. The results are presented in Table 2. As for the comparison risk analysis of fouling, agglomeration, and corrosion by using fly ash, the eucalyptus bark pellet ash retained mainly $\mathrm{SiO}_{2}$, $\mathrm{CaO}$, and $\mathrm{Al}_{2} \mathrm{O}_{3}(68.88-85.70 \%$ in the dry fuel when taken together) (Table 1). The $\mathrm{CaO}$ in ash produced through burning of the eucalyptus bark pellets decreased from 18.27 to $10.45-6.26 \%$ when kaolin was added. The levels of $\mathrm{CaO}$ particles in the fly 
ash were lower than the bottom ash. To characterize the ash fouling and slagging tendencies, equations (1)-(3) determined the probability of slagging, fouling, and agglomeration. The Al was $0.18-0.20$ (more than 0.17 but less than 0.34 ), signifying a tendency for slagging and fouling. The BAI was 0.190.60 (more than 0.15 ), signifying no agglomeration occurrence. The $\mathrm{R}_{\mathrm{b} / \mathrm{a}}$ was $0.84-1.61$ (less than 2.6), signifying no tendency for slagging and fouling (Table. 2).

\section{The oxide analyses of fly ash of pellets}

The fly ash of eucalyptus bark pellets with kaolin crystallized and caused further agglomeration. The main oxide in the fly ash was silicone oxide. The kaolin caused calcium oxide to decrease in the fly ash. The $\mathrm{CaO}$ reacted with potassium oxide and $\mathrm{SiO}_{2}$ to decrease the melting temperature, which caused the bottom ash to melt easily. This finding is consistent with previous research by Soerensen, Fjellerup and Henriksen ${ }^{12}$. The melting temperature changed according to the ratio of $\mathrm{K}_{2} \mathrm{O}$ and silicon. The increase of calcium caused the melting temperature of the ash to decrease. This finding is consistent with research by Mathiyanon, Satitrangsak, Sangvorakarn, Intrachandra and Chaiyaporn ${ }^{13}$.

Regarding absorption and chemical reactions of kaolin, this study found that kaolin was able to absorb potassium in the form of $\mathrm{KAI}_{2} \mathrm{Si}_{3} \mathrm{AlO}_{10}(\mathrm{OH})_{2}$ at $700-800{ }^{\circ} \mathrm{C}$. The potassium accumulated on the tube surface as muscovite at $900{ }^{\circ} \mathrm{C}$. The muscovite was mono crystalline and flaked and stacked thickly on the tube. The elementary compounds reacted to form Kalsilite $\left(\mathrm{KAISiO}_{4}\right)$ and $\mathrm{HCl}$, as represented in equation (5). The compound was a crystalline kaliophilite (leucite). The aluminum and silicate compound had a melting temperature range of $1165-1250^{\circ} \mathrm{C}$, which decreased as corrosion and fouling increased. The $\mathrm{KAI}_{2} \mathrm{Si}_{3} \mathrm{AlO}_{10}(\mathrm{OH})_{2}$ compound was able to separate into aluminum oxide $\left(\mathrm{Al}_{2} \mathrm{O}_{3}\right)$ and $\mathrm{SiO}_{2}$ at $850-1200$ ${ }^{\circ} \mathrm{C}$ without corrosion. The fly ash oxides affected corrosion of the chlorine and hydrochloride.

$$
\mathrm{Al}_{2} \mathrm{O}_{3}+2 \mathrm{SiO}_{2}+2 \mathrm{KCl}+\mathrm{H}_{2} \mathrm{O}=2 \mathrm{KAISiO}_{4}+2 \mathrm{HCl}
$$

The oxide analyses of agglomeration on the tube surface and bottom ash

Corrosion on the tube caused a decrease with added kaolin to the fuel. Table 3 shows the major oxide elements, which were $\mathrm{SiO}_{2}, \mathrm{Fe}_{2} \mathrm{O}_{3}$,
$\mathrm{Al}_{2} \mathrm{O}_{3}$, and $\mathrm{K}_{2} \mathrm{O}_{5}$. Erosion reduction due to compound oxides reduced the $\mathrm{Fe}_{2} \mathrm{O}_{3}$. The $\mathrm{Fe}_{2} \mathrm{O}_{3}$ values for the eucalyptus bark pellets with 5,10 , and $12 \%$ kaolin were $22.993,9.439$, and $28.477 \%$, respectively. Pellets with $10 \%$ kaolin expressed a reduction of $\mathrm{Fe}_{2} \mathrm{O}_{3}$ by $88.6 \%$ relative to pellets without kaolin.

The oxide analyses showed agglomeration of bottom ash, as presented in Table. 3. The agglomeration had more than $77.44 \%$ silicone oxide in all trials, and there was $13.6-24.4 \%$ agglomeration, which caused obstruction of air and affected combustion.

\section{Findings on steam boiler production}

There was a pressure range of 10-13 bar in the boiler and the fuel feed was controlled to maintain a continuous pressure of 10-12 bar. The eucalyptus pellets produced steam at $409.2 \mathrm{~kg}$ steam $/ \mathrm{h}$. Steam production rates were $377.4,366.3$, and $447.4 \mathrm{~kg}$ steam $/ \mathrm{h}$ for the pellets containing 5,10 , and $15 \%$ kaolin, respectively, as presented in Table 4. The pellets with $12 \%$ kaolin affected the leverage of the slagging on the furnace, which obstructed air and caused the average pressure to decrease to 7.4 bar. The efficiency of the boiler fuel with bark eucalyptus pellets containing $0,5,10$, and $12 \%$ kaolin was $53.6,48.5,39.2$, and $48.5 \%$, respectively. The cumulative effect of fouling on the surface tube was 283.3, 115.7, 64.0, and $53.3 \mathrm{~g} / \mathrm{m}^{2} . \mathrm{h}$, respectively (Table. 5), demonstrating a tendency for fouling to decrease when the additive was increased. Theis, Skrifvars, Hupa and $\operatorname{Tran}^{6}$ found the accumulation of fouling on tube surfaces from eucalyptus bark and oat straw to be 80 and $160 \mathrm{~g} / \mathrm{m}^{2} . \mathrm{h}$, respectively, findings which were 2.5 times lower than this study's findings. This study found that agglomeration decreased with the addition of kaolin (Table. 5). Eucalyptus bark pellets without kaolin had the highest agglomeration effect and also the highest effect on the lifetime of the boiler.

\section{CONCLUSION}

The elementary ash in eucalyptus bark affected the corrosion and efficiency of pipes in the boiler tube. The observation of 20 provinces in Northeast of Thailand, 64 eucalyptus wood chip factories were classified as 44 eucalyptus wood chip factories and 20 specific wood chip factories. 
Nakhon Ratchasima, Surin, and Buriram provinces had the most eucalyptus wood chip factories in descending order. The obtained eucalyptus bark pellets had $8 \mathrm{~mm}$ diameter, $715.0 \mathrm{~kg} / \mathrm{m}^{3}$ density and $11-13 \%$ w.b. moisture content. The proximate and ultimate values of eucalyptus bark were $\mathrm{C}, \mathrm{H}$, $\mathrm{N}, \mathrm{S}$ and $\mathrm{O}$. The $\mathrm{CaO}$ was the most oxide content $(62.66 \%)$ and the chorine content was $0.98 \%$. The $\mathrm{CaO}$ affected the distribution of the particles or aerosols to be adhesion surface tube during condensation. The corrosion was being gas phase of $\mathrm{Cl}, \mathrm{K}, \mathrm{Na}, \mathrm{S}$ and heavy metal other to reacted to change compounds gas was $\mathrm{KCl}, \mathrm{K}_{2} \mathrm{SO}_{4}$ and heavy metal compound which condensed on surface tube. The eucalyptus pellets were used as fuel which produced steam at $409.2 \mathrm{~kg} s t e a m / h$. The eucalyptus bark pellet with $12 \%$ kaolin was high steam production rate $(447.4 \mathrm{~kg}$ steam $/ \mathrm{h})$. The tendency for fouling decrease with the kaolin addition. The cumulative effect of fouling on the surface tube was 64.0 and $53.3 \mathrm{~g} / \mathrm{m}^{2}$.h for eucalyptus bark pellets containing 10 , and $12 \%$ kaolin respectively. The fouling decreased 77.4 and $81.2 \%$ respectively.

The bottom ash produced through burning of the eucalyptus bark pellets expressed a decrease in $\mathrm{CaO}$ from 62.66 to $15.64-9.74 \%$ which depended on the amount of kaolin addition. There were lower tendency for slagging and fouling, no agglomeration occurrence and no tendency for slagging and fouling. The $\mathrm{CaO}$ in fly ash produced through burning of the eucalyptus bark pellets decreased from 18.27 to $10.45-6.26 \%$ with kaolin addition. There were tendency for slagging and fouling, no agglomeration occurrence and no tendency for slagging and fouling.

The slagging experiment showed the slagging ash increased with kaolin more than $10 \%$. Thus, the $10 \%$ kaolin addition in eucalyptus bark pellet was the suitable content for fuel in boiler. There were high steam production rate, low cumulative effect of fouling agglomeration and slagging.

\section{ACKNOWLEDGMENTS}

The authors acknowledge the financial support given by the Energy Conservation Promotion Fund, Energy policy and Planning office, Ministry of Energy, and the institute of Research and Development, Suranaree University of Technology, Thailand.

\section{REFERENCES}

1. Arjharn, W. Report of Energy policy and Planning office, Ministry of Energy, Thailand, 2011.

2. Forest research and development bureau. The status of and trends on wood industry in Thailand. Retrieved on 9 January 2015 from: http://forprod.forest.go.th/forprod/ wood_industries/pdf, 2006.

3. Gonzalez, R.; Treasure, T.; Wright, J.; Saloni, D.; Phillips, R.; Abt, R. and Jameel, $H$. Biomass Bioenergy. 2011, 35, 755-766.

4. The Japan institute of energy. Asian Biomass Handbook. Retrieved on 9 January 2015 from: www.jie.or.jp/biomass/Asia BiomassHandbook/Thai/All_T.pdf, 2008.

5. Knoef, H.A.M. Handbook biomass gasification. 2nd ed., (BRG biomass technology group, Netherlands) 2012.

6. Theis, M.; Skrifvars, B.J.; Hupa, M. and Tran, H. Fuel. 2006, 85, 1125-1130.

7. Biglia, A.; Comba, L.; Fabrizio, E.; Gay, P. and Aimonino, D.R. Appl. Therm. Eng. 2017, 118, 638-651.
8. ASTM D3173 Standard test method for moisture in the analysis sample of coal and coke, (American Standard Testing Method, USA), 1991.

9. ASTMD1762-84 Standard methods for chemical analysis of wood charcoal, (American Standard Testing Method, USA), 1991.

10. ASTM D2015-77 Standard test methods for gross calorific value of solid fuel by the adiabatic bomb calorimeter, (American Standard Testing Method, USA) 1991.

11. DIN EN 2032 Gas-heated catering equipment, (Standard Test Method German Standards and Technical Rules, German) 1997.

12. Soerensen, L.H.; Fjellerup, J. and Henriksen, U. U.S. Patent No. 6615751 B1. Washington, DC; U.S. Patent and Trademark Office, 2003.

13. Mathiyanon, T.; Satitrangsak, P.; Sangvorakarn, S.; Intrachandra, N. and Chaiyaporn, W. Report of Energy policy and Planning office, Ministry of Energy, Thailand, 2010. 